\title{
KAJIAN APLIKASI TEKNIK INSEMINASI BUATAN DALAM PENINGKATAN GENETIK BOBOT BADAN TERNAK SAPI PERANAKAN ONGOLE DI SULAWESI UTARA
}

\author{
Manopo Jouke Hendrik*, Umar Paputungan, Wapsiaty Utiah
}

Fakultas Peternakan, Universitas Sam Ratulangi, Manado

\begin{abstract}
ABSTRAK
Penelitian ini dilakukan untuk mengevaluasi efektivitas aplikasi inseminasi buatan (IB) dibandingkan perkawinan alam (KA) terhadap prningakatn genetic bobot badan ternak sapi Peranakan Ongole (PO) yang melibatkan semen bersumber dari pejantan bangsa Ongole melalui sistem grading up di wilayah provinsi Sulawesi Utara. Data bobot badan hidup dikumpulkan dari semua induk $(n=404)$ yang dipelihara oleh peternak tradisional. Data induk sapi dewasa dikoreksi dengan penyesuaian umur enam tahun. Persilangan dari silsilah genetic yang digunakan KA dan AI dibagi ke dalam tiga kelompok induk dewasa, kelompok pertama persilangan KA tanpa grading up (G0), kelompok kedua persilangan IB dengan grading up memakai semen pejantan Ongole untuk generasi 1 (G1), dan kelompok ketiga persilangan IB dengan grading up melakai semen pejantan dikawinkan kelompok betina dewasa G1 menghasilkan induk dewasa generasi 2 (G2). Peningkatan genetik bobt hidup dari hasil persilangan kelompok G0, G1, dan G3 dianalisis dengan melibatkan parameter intensitas seleksi $(i)$, ketepatan seleksi $(r)$, standar deviasi genetik sifat yang diseleksi $(S D g)$, dan interval generasi $(L)$ diekespresikan per tahun. Hasil kajian ini menunjukkan bahwa komponen kritis adalah
\end{abstract}

\footnotetext{
*Korespondensi (corresponding author):
} Email : Manopo.hendrik@gmail.com peningkatan genetik dari sapi lokal melalui grading up memakai semen pejantan Ongole terseleksi melalui perkawinan IB yang menghasilkan G2 di Sulawesi Utara. Metode ini mampu meningkatkan menimal empat kali lipat dari bobot badan hidup kelompok hasil kawin alam melalui proporsi seleksi $48 \%$ sampai $10 \%$ betina unggul pada batas titik pangkas (truncation point) dari populasi ternak dibandingkan hal itu pada perkawina alam G0 dalam peningkatan genetic bobot hidup per tahun.

Kata Kunci. Inseminasi buatan, peningkatan genetic, pejantan sapi Ongole.

\section{ABSTRACT}

THE STUDY OF ARTIFICIAL INSEMINATION APPLICATION ON GENETIC IMPROVEMENT OF LIVE WEIGHT IN ONGOLE GRADE CATTLE AT NORTH SULAWESI PROVINCE. This research was conducted to evaluate the effective application of artificial insemination compared with natural breeding on genetic improvement by grading up system involving semen sourced from Ongole bull for the Indonesian-grade cattle at rural areas in Minahasa regency of North Sulawesi province, Indonesia. Data on animal live weight were collected from all cows $(\mathrm{n}=$ 404) kept by the traditional household farmers. Data of the cows were corrected by adjusting for the six years old of age. Breeding of beef genetic ancestors used the natural breeding (NB) and the artificial insemination (AI), divided into three cow groups with the first group of NB-mating without grading up (G0 cows), the second 
group of AI-mating with grading up using semen of Ongole bull for the first generation (G1 cows), and the third group of AI-mating with grading up using semen of Ongole bull for the second generation (G2 cows). The genetic improvements from breeding program of each G0, G1 and G2 were analyzed involving the selection intensity $(\boldsymbol{i})$, the accuracy of selection $(r)$, the genetic standard deviation of the trait under selection $(S D g)$, and the generation interval $(L)$ expressed in years. Results of this study showed that the critical components was the genetic development of local beef cattle by grading up using semen of the selected elite Ongole bull mated by AI method producing G2 in North Sulawesi province of Indonesia. This method increased genetically four hundred percents of live weight per year under $48 \%$ to $10 \%$ proportions of elite cows at the truncation points from the animal population compared with those of the natural mating of $\mathrm{G} 0$ in increasing genetic development for animal genetically live weight per year.

Key Words: artificial insemination, genetic development, Indonesian localgrade cattle, Ongole breed bull

\section{PENDAHULUAN}

Ternak sapi Peranakan Ongole (PO) memiliki kemampuan beradaptasi terhadap kondisi lingkunan panas dan lembab serta pakan kualitas rendah untuk menghasilkan daging dan tenaga untuk membajak lahan sebelum penanaman tanaman (Nichi et al., 2006; Paputungan et al., 2016). Di Sulawesi Utara, peningkatan pendapatan peternak sekitar empat puluh persent dapat dikontribusikan dari usaha pemeliharaan ternak sapi (Paputungan et al., 2018). Peningkatan pendapatan peternak bersama peningkatan populasi penduduk manusia memacu laju peningkatan permintaan kebutuhan protein hewani termasuk bersumber dari ternak sapi (Henchion et al., 2014, Isnaini et al., 2019).

$$
\text { Kelahiran anak sapi dengan }
$$
pertumbuhan dan bobot hidup unggul merupakan kunci peningkatan produksi daging (Isnaini et al., 2019). Dengan demikian, usaha terpenting meningkatkan performan reproduksi yang sejajar dengan perbaikan genetic ternak adalah penerapan inseminasi buatan (IB) di wilayah pedesaan (Morrell, 2011, Thundathil et al., 2016, Chawala et al., 2017). Saat ini, program pemerintah untuk peningkatan genetic ternak sapi lokal di wilayah pedesaan Indoesian adalah pemanfaatan semen bersumber dari pejantan sapi Ongole dari Balai Besar Inseminasi Buatan Singosari, Jawa Timur untuk kawasan Timur Indonesia tanpa masalah kesulitan melahirkan anak atau dystocia (Hendrik and Paputungan, 2016).

Keuntungan program IB dari pemerintah adalah memberikan kesempatan menggunakan keunggulan genetik dari pejantan sapi Ongole yang para peternak tidak mampu membelinya sebagai sumber bibit, sehingga disuplai oleh pemerintah. Untuk alasan inilah, maka tujuan kajian penelitian ini dilakukan untuk mengevaluasi efektivitas aplikasi inseminasi buatan (IB) dibandingkan 
perkawinan alam (KA) terhadap prningakatn genetic bobot badan ternak sapi Peranakan Ongole (PO) yang melibatkan semen bersumber dari pejantan bangsa Ongole melalui sistem grading up di wilayah provinsi Sulawesi Utara.

\section{MATERI DAN METODE PENELITIAN}

\section{Lokasi Penelitian}

Penelitan dilaksanakan di provinsi Suwessi Utara yang menerapkan perkawinan inseminasi buatan (IB) di pusat-pusat IB kecamatan dan perkawina alam (KA) ternak sapi oleh peternak di wilayah pedesaan Kabupaten Minahasa. Wilayah pedesaan ini dikategorikan area pertanian dengan berbagai ketingian dari permukaan laut (dpl) berkisar 1-600 m. Ketinggian tempat ini berada pada kisaran suhu 25 sampai $28^{\circ} \mathrm{C}$ dan kelembaban berkisar 70 sampai 80 persen.

\section{Ternak Penelitian}

Total ternak sapi betina dewasa 404 ekor digunakan dalam kajian ini. Semua ternak yang dilibatkan adalah induk sapi sehat tanpa bunting, umur berkisar dari empat sampai enam tahun. Umur tentukan melalui kondisi gigi (Paputungan et al., 2015) dengan indikasi: induk memperlihatkan enam gigi susu telah berubah menunjukkan umur tiga setengah sampai empat setengah tahun, induk memperlihatkan delapan gigi susu telah berubah menunjukkan umur sudah di atas lima tahun. Indikator gigi ini diverifikasi berdasarkan informasi peternak dan observasi langsung saat periode pengukuran morfometrik ternak.

Catatan bobot hidup induk dewasa setelah melahirkan anak dilakukan saat pencatatan selama lima tahun (2014-2019) yang dilibatkan dalam kajian ini. Semua induk dewasa dipelihara pada wilayah yang dimiliki peternak dengan 182 peternak. Induk sapi dewasa dibahagi ke dalam tiga kelompok dengan komposis genetik yang berbeda. Kelompok pertama dari G0 adalah total 147 induk dewasa dari hasil kawin alam (KA) dari semua tetua betina dan pejantan sapi lokal (LL) dengan komposisi genetik 100 sapi lokal milik oleh 67 peternak. Kelompok kedua dari G1 adalah total 123 induk dewasa dari hasil kawin inseminasi buatan (IB) antara induk sapi Lokal (LL) dengan pejantan Ongole (OO) dengan komposisi genetik 50\% induk sapi Lokal dan 50\% Ongole $\left(\mathbf{L}^{1 / 2} \mathbf{O}^{1 / 2}\right)$ milik oleh 54 peternak. Kelompok ketiga dari G2 adalah total 134 induk dewasa dari hasil kawin IB antara induk G1 $\left(\mathrm{L}^{1 / 2} \mathrm{O} 1 / 2\right)$ dan pejantan Ongole (OO) dengan kompsisi genetic 25\% induk sapi Lokal dan $75 \%$ Ongole $\left(\mathrm{L}^{\left.1 / 4 \mathrm{O}^{3} / 4\right)}\right.$ milik 61 peternak.

Informasi silsilah perkawinan generasi induk dewasa dalam kajian ini dibuat berdasarkan penelusuran dari pusat- 
Tabel 1. Skema Pengembangbiakan Ternak Sapi Kawin Alam (KA) dan Inseminasi Buatan (IB) Dalam Kajian Penelitian Di Sulawesi Utara

\begin{tabular}{|c|c|c|}
\hline $\begin{array}{l}\text { KA tanpa grading up (G0) } \\
\text { Induk dewasa }\end{array}$ & $\begin{array}{l}\text { IB dengan grading up pakai } \\
\text { semen pejantan Ongole untuk } \\
\text { generasi pertama (G1) Induk }\end{array}$ & $\begin{array}{l}\text { IB dengan grading up pakai } \\
\text { semen pejantan Ongole untuk } \\
\text { generasi kedua (G2) Induk }\end{array}$ \\
\hline 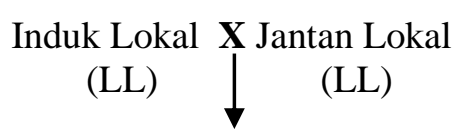 & $\begin{array}{c}\text { Induk Lokal X Jantan Ongole } \\
(\mathrm{LL}) \backslash \\
\qquad \begin{array}{l}(\mathrm{OO})\end{array}\end{array}$ & $\begin{array}{c}\text { Induk G1 } \\
\left(\mathrm{L}^{1 / 2} \mathrm{O}^{1 / 2}\right)\end{array}$ \\
\hline $\begin{array}{l}\text { Induk G0 (100\% LL) } \\
\text { (147 ekor) } \\
(304.02 \pm 44.41 \mathrm{~kg})\end{array}$ & $\begin{array}{l}\text { Induk } \mathrm{G} 1\left(\mathrm{~L}^{1 / 2 \mathrm{O}} 1 / 2\right) \\
(123 \text { ekor }) \\
(335.97 \pm 35.17 \mathrm{~kg})\end{array}$ & $\begin{array}{c}\text { Induk } \mathrm{G} 2\left(\mathrm{~L}^{\left.1 / 4 \mathrm{O}^{3} / 4\right)}\right. \\
(134 \text { ekor }) \\
(383.24 \pm 22.74 \mathrm{~kg})\end{array}$ \\
\hline
\end{tabular}

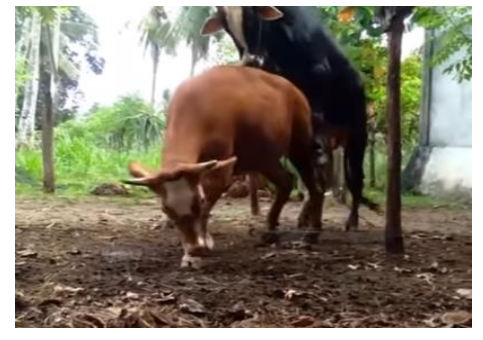

Foto 1a. Metode KA sapi induk Lokal (LL) dengan jantan Lokal (LL) mewariskan generasi berikut (LL), G0

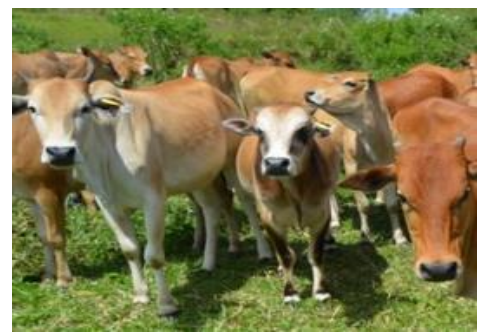

Foto 1b. Induk sapi G0 representasi observasi bobot hidup ternak

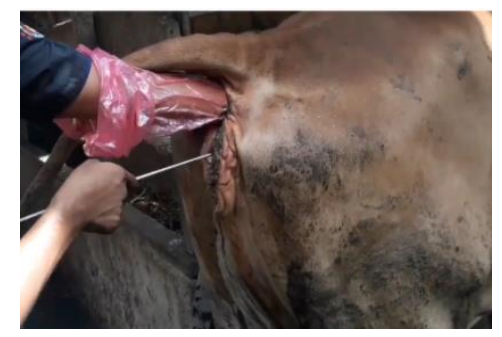

Foto 2a. Metode IB sapi induk Lokal (LL) dengan semen jantan Ongole (OO) mewariskan generasi pertama $\left(\mathrm{L}^{1 / 2} \mathrm{O}^{1 / 2}\right), \mathrm{G} 1$

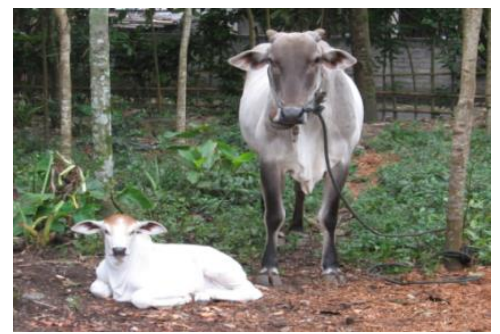

Foto 2b. Induk sapi G1 representasi observasi bobot hidup ternak

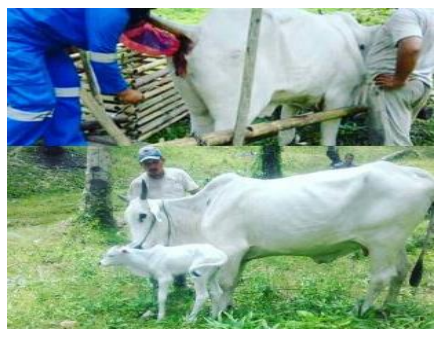

Foto 3a. Metode IB sapi induk G1 $\left(\mathrm{L}^{1 / 2} \mathrm{O}^{1 / 2}\right)$ dengan semen jantan Ongole mewariskan generasi kedaua $\left(\mathrm{L}^{1 / 4} \mathrm{O}^{3 / 4}\right), \mathrm{G} 2$

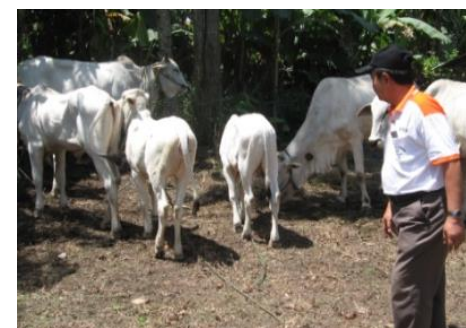

Foto 3b. Induk sapi G2 representasi observasi bobot hidup ternak pusat IB di kecamatan seperti disajikan dalam Tabel 1 dilengkapi representasi beberapa foto.

\section{Pengumpulan Data}

Bobot hidup ternak diukur memakai ukuran morfometrik ternak yang dihitung berdasarkan formulasi dalam Paputungan $e t$ al. (2013). Data induk betina dewasa ini dikoreksi melalui penyesuaian pada umur enam tahun guna mengeliminasi efek perbedaan umur (Brito et al., 2002, Zulkharnaim et al., 2010; Bhakat et al., 2011) melalui penggunaan formulasi rumus: 
$x_{i-\text { corrected }}=\frac{\bar{x}_{\text {standard }}}{\bar{x}_{\text {observed }}} \quad$ X $x_{i \text {-observed }}$

Data dari penyesuaian umur dianalisis menggunakan software sederhana melaui fungsi program statisti dalam Excel XP 2007.

\section{Analisis Data}

Data bobot hidup ternak dianalisis memakai General Linear Models (GLM) procedure of SAS (2016) dengan model matematik (Byrkit, 1987; Steel and Torrie, 1993) sebagai berikut:

$Y_{i j k}=\mu+B_{i}+C_{j}+e_{i j k}$

Dimana, $\mathrm{Y}_{\mathrm{ijk}}=$ observasi dari genotype induk ke- $\mathrm{k}^{\text {th }}$ dengan kelompok genotype induk tetua ke-j ${ }^{\text {th }}$ dan kelompok pejantan tetua genotype $\mathrm{ke} \mathrm{i}^{\text {th. }} \mu$ = rata-rata umum terhadap semua ternak dalam penelitian; $\mathrm{B}_{\mathrm{i}}=$ efek tetap berkaitan dengan kelompok genotype pejantan tetua $\mathrm{ke}-\mathrm{i}^{\text {th }} \quad(\mathrm{i}=2$, kelompok KA pejantan Lokal, pejantan Ongole sumber semen dipakai dalam program IB),

$\mathrm{C}_{\mathrm{j}}=$ efek tetap berkaitan dengan kelompok genotype induk tetua $\mathrm{ke}-\mathrm{j}^{\text {th }}(\mathrm{j}=3, \mathrm{G} 0, \mathrm{G} 1$, G2), $\mathrm{e}_{\mathrm{ijk}}=$ efek acak khusus pada setiap individu induk.

Perbandingan rataan significant ukuran bobot hidup dalam kelompok genotype ternak diuji melakai least significant different (Byrkit, 1987; Mendenhall, 1987). Seleksi diferensial (S) yang menentkan superioritas induk tetuat terseleksi di atas rata-rata populasi dianalisis dengan rumus (Van Vleck et al., 1987; Thekkoot, 2017) sebagai berikut:

$$
\mathbf{S}=\overline{\boldsymbol{x}}_{\text {Selected }}-\overline{\boldsymbol{x}}_{\text {Population }}
$$

Dimana, $\overline{\boldsymbol{x}}$ Selected adalah rata-rata bobothidup induk parental terseleksi dan $\overline{\boldsymbol{x}}$ Population adalah rata-rata bobot hidup populasi induk tetua. Seleksi diferensial (S) distandarisai dengan membaginya dengan standar deviasi (SD) dari bobot hidup populasi induk. Seleksi diferensial terstandarisasi, dinamakan intensitas seleksi (i) diekspresikan dalam formulasi (Van Vleck et al., 1987; Thekkoot, 2017) sebagai berikut:

$$
\begin{gathered}
i=\left(\frac{S}{S D}\right)= \\
\left(\frac{\bar{x} \text { Selected }-\overline{\boldsymbol{x}} \text { Population }}{S D}\right)
\end{gathered}
$$

Dari persamaan di atas, semakin tinggi nilai $\mathrm{S}$, semakin tinggi adanya peningkatan genetik (G).

Peningkatan genetik $\left(\Delta_{G}\right)$ per tahun dari program pemuliaan tergantung empat faktorkunci (Thekkoot, 2017) termasuk intensitas seleksi (i), ketepatan selecsi $(r)$, standar deviasi genetik sifat yang diselesi $(S D g)$, generasi interval $(L)$ per tahun, dengan formulasi sebagai berikut:

$$
\Delta_{G}=\left(\frac{i . r . S D_{g}}{L}\right)
$$

Ketepatan seleksi ( $r$ ) didasarkan terhadap korelasi tetua "full sib" sebesar 0.71, korelasi tetua "Half sib" sebesar 0.50 dan 
korelasi antar keturunan "Half sib" sebesar 0.10 (Ellen et al., 2007). Rata generasi interval $(L)$ induk sapi dewasa Lokal per tahun adalah 2.7 tahun (Paputungan et al., 2018).

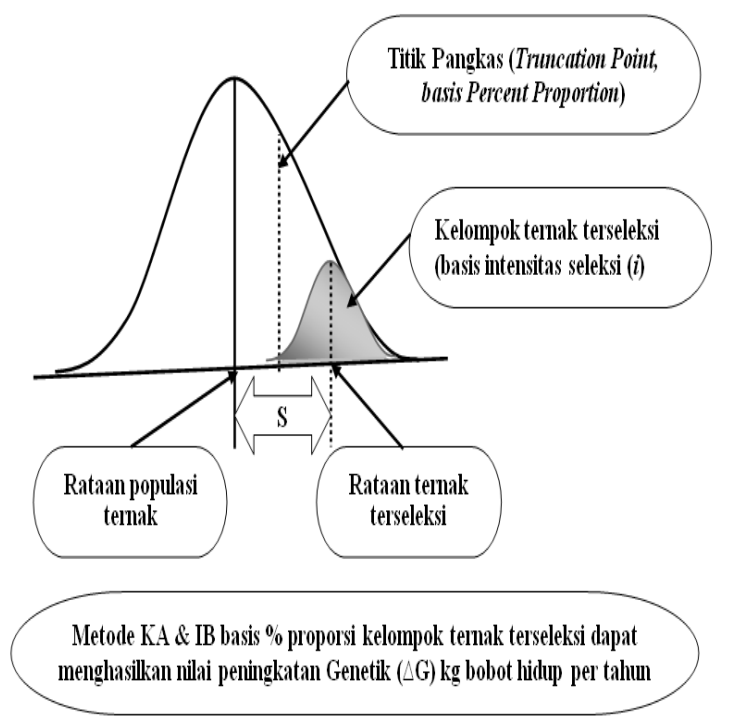

Gambar 1: Distribusi populasi induk sapi betina dewasa dan ternak terseleksi pada titik pangkas berbasis persentase proporsi seleksi ternak dan basis intensitas seleksi (i) tertentu untuk menghasil nilai peningkatan genetik bobot hidup ternak per tahun.

\section{HASIL DAN PEMBAHASAN}

Hasil dalam Tabel 2 menunjukkan rata-rata bobot hidup oleh kelompok genotype induk hasil kawin alam (KA) dan kelompok induk hasil inseminasi buatan (IB). Dari total 404 induk tetua, sebanyak 123 induk dilahirkan dari kawin IB memakai induk Lokal (LL) dan semen pejantan Ongole (OO) menghasilkan induk dewasa (G1) bergenotype $\left(\mathrm{L}^{1} / 2 \mathrm{O}^{1 / 2}\right)$, induk- induk sebanyak 134 betina dewasa yang dilahirkan dari kawin IB memakai induk G1 $\left(\mathrm{L}^{1 / 2} \mathrm{O}^{1 / 2}\right)$ dan semen semen pejantan Ongole (OO) menghasilkan induk dewasa (G2) bergenotype $\left(\mathrm{L}^{1 / 4} \mathrm{O}^{3} / 4\right)$, dan indukinduk sebanyak 147 betina dewasa yang dilahirkan dari kawin alam (KA) induk betina Lokal (LL) dengan pejantan sapi Lokal(LL) menghasilkan induk dewasa G0 bergenotype (LL). Rata-rata bobot hidup keseluruhan yang telah disesuaikan pada umur 6 tahun adalah 340,02 $\pm 48,56 \mathrm{~kg}$.

Rata-rata bobot hidup genotype induk betina $\mathrm{G} 2\left(\mathrm{~L}^{1 / 4} \mathrm{O}^{3} / 4\right)$, genotype induk betina $\mathrm{G} 1\left(\mathrm{~L}^{1 / 2} \mathrm{O}^{1 / 2}\right)$ dan genotype induk betina $\mathrm{G} 0$ (LL) menunjukkan masing-masing secara berurutan $383,24 \pm 22,74 \mathrm{~kg}, 335,97$ $\pm 35,17 \mathrm{~kg}$, dan $304,02 \pm 44,41 \mathrm{~kg}$. Selanjutnya, rata-rata bobot hidup gabungan kedua genotype induk $\mathrm{G} 2$ dengan genotype induk G0 dan gabungan kedua genotype G1 dengan genotype G0, masingmasing secara berurutan menujukkan $341,80 \pm 53,34 \mathrm{~kg}$ dan $318,57 \pm 43,42 \mathrm{~kg}$ (Tabel 2). Rata-rata tertinggi bobot hidup untuk proporsi 10\% G2 dari total gabungan genotype induk G0 + G2 adalah 415,79 \pm $14,53 \mathrm{~kg}$ (Table 2). Sementara rata-rata tertinggi bobot hidup proporsi $10 \% \mathrm{G} 1$ dari gabungan genotype induk G0 + G1 adalah $382,93 \pm 8,45$ (Tabel 2). Hasil uji statistik rata-rata genotype induk $\mathrm{G} 2$, induk $\mathrm{G} 1$ dan induk G0 berbeda sangat nyata $(\mathrm{P}<0.001)$. 
Tabel 2. Rata-rata dan standar deviasi bobot hidup sapi induk dewasa yang dilahirkan dari kawin alam (KA) sapi Lokal dan dari kawin inseminasi buatan (IB) di wilayah Sulawesi Utara

\begin{tabular}{|c|c|c|c|}
\hline $\begin{array}{l}\text { Kelompok genotype induk sapi berbasis persentase } \\
\text { proporsi dari populasi }\end{array}$ & $\mathbf{N}$ & $\begin{array}{l}\text { Bobot hidup } \\
(\mathrm{kg})\end{array}$ & $\begin{array}{l}\text { KK } \\
(\%)\end{array}$ \\
\hline Rata-rata semua G2 $\left(\mathrm{L}^{1 / 4} \mathrm{O}^{3} / 4\right), \mathrm{G1}\left(\mathrm{L}^{1 / 2} \mathrm{O}^{1} / 2\right)$ \& G0 $(\mathrm{LL})$ : & 404 & $340,02 \pm 48,56$ & 14,28 \\
\hline Rata-rata kelompok genotype induk G2 (L1/4O3/4) & 134 & $383,24 \pm 22,74^{\mathrm{a}}$ & 5,93 \\
\hline Rata-rata kelompok genotype induk G1 ( $\left.\mathrm{L}^{1} / 2 \mathrm{O} 1 / 2\right)$ & 123 & $335,97 \pm 35,17^{\mathrm{b}}$ & 10,47 \\
\hline Rata-rata kelompok genotype induk G0 (LL) & 147 & $304,02 \pm 44,41^{\mathrm{c}}$ & 14,61 \\
\hline \multicolumn{4}{|c|}{$\begin{array}{l}\text { Titik pangkas proporsi tiap G2 }(n=134), G 1(n=123), G 0(n=147) \\
\text { dalam G2+G0 }(n=281) \& \text { G1+G0 }(n=270) \text { : }\end{array}$} \\
\hline Rata-rata induk G2 $\left(\mathrm{L}^{1 / 4 \mathrm{O}^{3} / 4}\right)+$ induk G0 (LL) & 281 & $341,80 \pm 53,34^{\mathrm{d}}$ & 15,61 \\
\hline Rata-rata induk G1 (L1/2O1/2) + induk G0 (LL) & 270 & $318,57 \pm 43,42 \mathrm{e}$ & 13,63 \\
\hline \multicolumn{4}{|l|}{$\begin{array}{l}\text { Titik pangkas proporsi } 10 \% \mathrm{G} 2(\mathrm{n}=28) \text { and } 10 \% \mathrm{G1}(\mathrm{n}=27) \\
\text { dalam G2+G0 }(\mathrm{n}=281) \& \mathrm{G} 1+\mathrm{G0}(\mathrm{n}=270) \text { : }\end{array}$} \\
\hline $\begin{array}{l}\text { Rata-rata dari } 10 \% \mathrm{G} 2\left(\mathrm{~L}^{1 / 4 \mathrm{O}^{3} / 4}\right) \text { dalam } \mathrm{G} 2+\mathrm{G} 0 \\
(\mathrm{~N}=281)\end{array}$ & 28 & $415,79 \pm 14,53^{\mathrm{i}}$ & 3,49 \\
\hline $\begin{array}{l}\text { Rata-rata dari } 10 \% \text { G1 }\left(\mathrm{L}^{1} \frac{1}{2} \mathrm{O} 1 / 2\right) \text { dalam } \mathrm{G} 1+\mathrm{G} 0 \\
(\mathrm{~N}=270)\end{array}$ & 27 & $382,93 \pm 8,45^{\mathrm{a}}$ & 2,21 \\
\hline \multicolumn{4}{|l|}{$\begin{array}{l}\text { Titik pangkas proporsi } 50 \% \text { induk elite terseleksi }(n=73) \\
\text { dari populasi G0 }(N=147) \text { : }\end{array}$} \\
\hline Rata-rata tertinggi bobot hidup dari total G0 (LL) & 73 & $335,60 \pm 43,97^{\mathrm{d}}$ & 13,10 \\
\hline \multicolumn{4}{|c|}{$\begin{array}{l}\text { Titik pangkas proporsi } 40 \% \text { induk elite terseleksi }(n=59) \\
\text { dari populasi G0 }(N=147) \text { : }\end{array}$} \\
\hline \multicolumn{4}{|c|}{$\begin{array}{l}\text { Titik pangkas proporsi } 30 \% \text { induk elite terseleksi }(n=48) \\
\text { dari populasi G0 }(\mathrm{N}=147) \text { : }\end{array}$} \\
\hline Rata-rata tertinggi bobot hidup dari total G0 (LL) & 48 & $358,21 \pm 37,78^{f}$ & 10,55 \\
\hline \multicolumn{4}{|c|}{$\begin{array}{l}\text { Titik pangkas proporsi } 20 \% \text { induk elite terseleksi }(n=29) \\
\text { dari populasi G0 }(\mathrm{N}=147) \text { : }\end{array}$} \\
\hline Rata-rata tertinggi bobot hidup dari total G0 (LL) & 29 & $396,84 \pm 23,98^{\mathrm{g}}$ & 6,04 \\
\hline \multicolumn{4}{|c|}{$\begin{array}{l}\text { Titik pangkas proporsi } 10 \% \text { induk elite terseleksi }(n=15) \\
\text { dari populasi G0 }(N=147) \text { : }\end{array}$} \\
\hline Rata-rata tertinggi bobot hidup dari total G0 (LL) & 15 & $404,21 \pm 14,19^{\mathrm{h}}$ & 3,51 \\
\hline $\begin{array}{l}\text { Keterangan: Nilai yang memiliki superscript berbeda dala } \\
(\mathrm{p}<0.01) . \mathrm{G} 0=\mathrm{KA} \text { memakai pejantan Lokal menghasilkan } \mathrm{g} \\
\text { pejantan Ongole, } \mathrm{G} 1=\text { perkawinan } \mathrm{IB} \text { dengan grading up } \\
\text { menghasilkan induk generasi pertama, } \mathrm{G} 2=\text { perkawinan }\end{array}$ & lom & ng sama berbeda $\mathrm{s}$ & $\begin{array}{l}\text { ifikan } \\
\text { up dari } \\
\text { untuk }\end{array}$ \\
\hline
\end{tabular}

Koefisien keragaman (KK) untuk rata-rata G2, G1 dan G0 masing-masing secara berurutan adalah 5,93\%, 10,47\%, dan $14,61 \%$ (Tabel 2). Nilai KK dari G0 dan G1 dapat diketegorikan variasi tinggi, sedangkan nilai KK dari G2 dapat dikategorikan variasi rendah (Kurnianto 2010). Nilai-nilai KK dari bobot hidup ini 
menunjukkan bahwa kelompok induk G2 lebih seragam dibandingkan kelompok induk-induk G1 dan G0 yang lebih bervariasi, dimana variasi tinggi ini membutuhkan adanya strategi seleksi lebih lanjut dalam peningkatan mutu genetik (Ellen et al., 2007; Eidan, 2016).

Persentase proporsi 50\%, 40\%, $30 \%$, 20\%, dan 10\% seleksi induk-induk unggul dari total induk G0 $(\mathrm{N}=147)$ dianalisis nilai rata-rata dari masing-masing proporsi di atas dan menunjukkan rata-rata bobot hidup masing-masing secara berurutan $335,60,346,66,358,21,396,84$ and 404,21 (Tabel 2). Semakin rendah proporsi dari induk-induk unggul terseleksi dari total populasi induk G0, semakin tinggi nilai rata-rata bobot hidup induk terseleksi (Thekkoot, 2017).

Proporsi titik pangkas $48 \%$ induk G2 hasil IB ( $n=134)$ dari populasi gabungan induk G2 dengan induk G0 (N=281) menunjukkan nilai seleksi diferensial (S) bobot hidup 41,44 kg, nilai intensitas seleksi (i) 0,76 dan hasil peningkatan genetik $\left(\Delta_{G}\right)$ bobot hidup $10,66 \mathrm{~kg}$ per tahun (Tabel 3). Proporasi titik pangkas $10 \%$ induk $\mathrm{G} 2$ unggul terseleksi $(n=28)$ dari populasi gabungan induk G2 dengan induk G0 (N=281) menunjukkan kenaikan nilai $\mathrm{S}$ bobot hidup menjadi $73,99 \mathrm{~kg}$, nilai $\boldsymbol{i}$ menjadi 1,39 dan hasil peningkatan genetik $\left(\Delta_{G}\right)$ bobot hidup sebesar $19,46 \mathrm{~kg}$ per tahun (Tabel 3). Dari formulasi di atas, semakin tinggi nilai intensitas seleksi $(\boldsymbol{i})$, semakin tinggi hasil peningkatan genetik $\left(\Delta_{G}\right)$ bobot hidup, karena nilai intensitas seleksi $(\boldsymbol{i})$ tergantung persentase proporsi titik pangkas ternak terseleksi sebagai tetua unggul untuk mewariskan sifat-sifat ekonomis terhadap generasi berikutnya (Thekkoot, 2017).

Analisi yang sama dilakukan juga terhadap titik pangkas proporsi $45 \%$ induk G1 dan terakhir menunjukkan hasil peningkatan genetik $\left(\Delta_{G}\right)$ bobot hidup sebesar 3,22 kg per tahun, yakni lebih kecil dibandingkan hasil peningkatan genetik $\left(\Delta_{G}\right)$ bobot hidup dari G2 $(10,66 \mathrm{~kg}$ per tahun). Titik pangkas proporsi 10\% \% induk G1 unggul terseleksi $(n=27)$ dari populasi gabungan induk G1 dengan induk G0 (N=270) menunjukkan kenaikan hasil peningkatan genetik $\left(\Delta_{G}\right)$ bobot hidup sebesar 12,16 kg per tahun, lebih rendah dibandingkan hasil peningkatan genetik ( $\Delta_{G}$ ) bobot hidup G2 (19,46 kg/tahun) seperti terlihat dalam Tabel 3. Titik pangkas proporsi 50\%, 40\%, 30\%, 20\%, dan $10 \%$ induk unggul terselesi dari total populasi induk G0 $(\mathrm{N}=147)$ dapat meningkatkan nilai genetik $\left(\Delta_{G}\right)$ bobot hidup induk (kg/tahun), yakni secara beurutan sebesar 1,17, 1,58, 2,01, 3,44, dan 10,04 kg per tahun (Tabel 4). Pengurangan 
titik pangkas proporsi induk unggul terseleksi dari total populasi G0, menunjukkan nilai peningkatan genetik $\left(\Delta_{G}\right)$ semakin besar terhadap bobot hidup sesuai pernyataan Thekkoot (2017).

Umumnya dalam pemuliaan genetik ternak menyeleksi rata-rata sifat tertinggi dari titik pangkas (truncation point). Individu ternak sabagai tetua diseleksi jika bobot hidup melebihi suatu nilai batas titik pangkas. Seleksi berbasis titik pangkas menghasilkan perbedaan antara rata-rata bobot hidup induk terseleksi sebagai tetua dan rata-rata keseluruhan populasi, yakni seleksi diferensial (S), yang menentukan superioritas induk tetua terseleksi di atas rata-rata keseluruhan individu dalam

Table 3. Analisis Peningkatan Genetik dari Proporsi Berbeda pada Induk Hasil KA (G0) dan Induk Hasil IB (G1 dan G2) dalam Populasi

\begin{tabular}{|c|c|}
\hline $\begin{array}{l}\text { Peningkatan Genetik dari proporsi berbeda pada induk unggul G1 } \\
\text { dan G2 }\end{array}$ & Nilai \\
\hline \multicolumn{2}{|l|}{$\begin{array}{l}\text { Titik pangkas proporsi } 48 \% \text { induk } G 2 \text { terseleksi }(n=134) \text { dari populasi } \\
\text { induk } G 2+\text { induk } G 0(N=281) \text { : }\end{array}$} \\
\hline Seleksi diferensial $(\mathbf{S})$ bobot hidup $(\mathrm{kg}$ ) oleh kelompok induk G2 terseleksi & 41,44 \\
\hline Intensitas seleksi (i) kelompok induk G2 terseleksi & 0,76 \\
\hline $\begin{array}{l}\text { Peningkatan Genetik }\left(\Delta_{G}\right) \text { bobot hidup }(\mathrm{kg}) \text { kelompok induk G2 } \\
\text { terseleksi/tahun }\end{array}$ & 10,66 \\
\hline \multicolumn{2}{|l|}{$\begin{array}{l}\text { Titik pangkas proporsi } 10 \% \text { induk } \mathrm{G} 2 \text { terseleksi }(\mathrm{n}=28) \text { dari populasi } \\
\text { induk } \mathrm{G} 2+\text { induk } \mathrm{G} 0(\mathrm{~N}=\mathbf{2 8 1}) \text { : }\end{array}$} \\
\hline Seleksi diferensial $(\mathbf{S})$ bobot hidup $(\mathrm{kg}$ ) oleh kelompok induk G2 terseleksi & 73,99 \\
\hline Intensitas seleksi (i) kelompok induk G2 terseleksi & 1,39 \\
\hline $\begin{array}{l}\text { Peningkatan Genetik }\left(\Delta_{G}\right) \text { bobot hidup }(\mathrm{kg}) \text { kelompok induk G2 } \\
\text { terseleksi/tahun }\end{array}$ & 19,46 \\
\hline \multicolumn{2}{|l|}{$\begin{array}{l}\text { Titik pangkas proporsi } 45 \% \text { induk } G 1 \text { terseleksi }(n=123) \text { dari populasi } \\
\text { G1 + G0 }(N=270) \text { : }\end{array}$} \\
\hline Seleksi diferensial $(\mathbf{S})$ bobot hidup $(\mathrm{kg})$ oleh kelompok induk G1 terseleksi & 17,4 \\
\hline Intensitas seleksi (i) kelompok induk G1 terseleksi & 0,40 \\
\hline $\begin{array}{l}\text { Peningkatan Genetik }\left(\Delta_{G}\right) \text { bobot hidup }(\mathrm{kg}) \text { kelompok induk G1 } \\
\text { terseleksi/tahun }\end{array}$ & 3,22 \\
\hline $\begin{array}{l}\text { Titik pangkas proporsi } 10 \% \text { induk } G 1 \text { terseleksi }(n=27) \text { dari populasi } \\
\text { induk } G 1+\text { induk } G 0(N=270) \text { : }\end{array}$ & \\
\hline Seleksi diferensial $(\mathbf{S})$ bobot hidup $(\mathrm{kg}$ ) oleh kelompok induk G1 terseleksi & 64,36 \\
\hline Intensitas seleksi (i) kelompok induk G1 terseleksi & 1,48 \\
\hline $\begin{array}{l}\text { Peningkatan Genetik }\left(\Delta_{G}\right) \text { bobot hidup }(\mathrm{kg}) \text { kelompok induk G1 } \\
\text { terseleksi/tahun }\end{array}$ & 12,16 \\
\hline
\end{tabular}


Table 4. Analisis Peningkatan Nilai Genetik dari Titik Pangkas Proporsi yang Berbeda dari Induk Kawin Alam (G0)

\begin{tabular}{|c|c|}
\hline Peningkatan Genetik dari Proporsi Induk Unggul Terseleksi G0 & Nilai \\
\hline \multicolumn{2}{|l|}{ Proporsi 50\% induk unggul terseleksi $(n=73)$ dari populasi G0 $(\mathrm{N}=147)$ : } \\
\hline Seleksi diferensial $(\mathbf{S})$ bobot hidup $(\mathrm{kg})$ dari kelompok induk terselesi & 31,58 \\
\hline Intensitas seleksi $(\boldsymbol{i})$ dari kelompok induk terselesi & 0,71 \\
\hline $\begin{array}{l}\text { Peningkatan Genetik }\left(\Delta_{G}\right) \text { bobot hidup }(\mathrm{kg}) \text { kelompok induk terselesi } \\
\text { /tahun }\end{array}$ & 1,17 \\
\hline \multicolumn{2}{|c|}{ Proporsi $40 \% \%$ induk unggul terseleksi $(n=59)$ dari populasi G0 $(N=147)$ : } \\
\hline Seleksi diferensial $(\mathbf{S})$ bobot hidup $(\mathrm{kg})$ dari kelompok induk terselesi & 42,64 \\
\hline Intensitas seleksi $(\boldsymbol{i})$ dari kelompok induk terselesi & 0,96 \\
\hline $\begin{array}{l}\text { Peningkatan Genetik }\left(\Delta_{G}\right) \text { bobot hidup }(\mathrm{kg}) \text { kelompok induk terselesi } \\
\text { /tahun }\end{array}$ & $\mathbf{1 , 5 8}$ \\
\hline Proporsi $30 \%$ induk unggul terseleksi $(n=48)$ dari populasi $G 0(N=$ & \\
\hline Seleksi diferensial $(\mathbf{S})$ bobot hidup (kg) dari kelompok induk terselesi & 54,19 \\
\hline Intensitas seleksi $(\boldsymbol{i})$ dari kelompok induk terselesi & 1,22 \\
\hline $\begin{array}{l}\text { Peningkatan Genetik }\left(\Delta_{G}\right) \text { bobot hidup }(\mathrm{kg}) \text { kelompok induk terselesi } \\
\text { /tahun }\end{array}$ & 2,01 \\
\hline Proporsi $20 \%$ induk unggul terseleksi $(n=48)$ dari populasi $G 0(N=$ & \\
\hline Seleksi diferensial $(\mathbf{S})$ bobot hidup (kg) dari kelompok induk terselesi & 92,82 \\
\hline Intensitas seleksi $(\boldsymbol{i})$ dari kelompok induk terselesi & 2,09 \\
\hline $\begin{array}{l}\text { Peningkatan Genetik }\left(\Delta_{G}\right) \text { bobot hidup }(\mathrm{kg}) \text { kelompok induk terselesi } \\
\text { /tahun }\end{array}$ & 3,44 \\
\hline Proporsi $10 \%$ induk unggul terseleksi $(n=48)$ dari populasi $G 0(N=$ & \\
\hline Seleksi diferensial $(\mathbf{S})$ bobot hidup $(\mathrm{kg})$ dari kelompok induk terselesi & 100,19 \\
\hline Intensitas seleksi $(\boldsymbol{i})$ dari kelompok induk terselesi & 2,26 \\
\hline $\begin{array}{l}\text { Peningkatan Genetik }\left(\Delta_{G}\right) \text { bobot hidup }(\mathrm{kg}) \text { kelompok induk terselesi } \\
\text { /tahun }\end{array}$ & 10,04 \\
\hline
\end{tabular}

populasi (Van Vleck et al., 1987; Thekkoot, 2017) sebagaimana pada Gambar 1.

Dalam kajian ini, aplikasi IB membantu meningkatkan bobot hidup dalam populasi induk ternak melalui pemanfaatan perbedaan genetik antara seluruh yang ada dengan pejantan Ongole superior sehingga kenaikan nilai genetik bobot hidup tercapai pada generasi selanjutnya (Thekkoot, 2017). Mekanisme dasar dalam proses ini adalah meningkatkan frekuensi gen-gen yang diinginkan dalam populasi dan mencegah genetik inferior dari individu berkembang 
pada generasi berikutnya. Dalam kajian ini, aplikasi IB yang melibatkan proporsi $48 \%$ induk G2 diantara semua populasi induk G0 dan G2 dari grading up kedua, mampu meningkatkan kenaikan genetik $\left(\Delta_{\mathrm{G}}\right)$ bobot hidup 10,66 kg/tahun di wilayah Sulawesi Utara. Namun, aplikasi IB yang melibatkan proporsi $45 \%$ induk G1 diantara semua populasi induk G0 (LL) dan G1 ( $\left.\mathrm{L}^{1 / 2} \mathrm{O}^{1} \frac{1}{2}\right)$ dari grading up pertama, hanya mampu meningkatkan kenaikan genetik $\left(\Delta_{\mathrm{G}}\right)$ bobot hidup 3,22 kg/tahun, yang lebih rendah dari hasil grading up generasi kedua, G2 $\left(\mathrm{L}^{1 / 4 \mathrm{O}^{3} / 4}\right)$ di atas (Tabel 4). Material genetik induk Lokal dalam G1 berkurang 25\% dan disubstitusi dengan 25\% material genetik potensial dari pejantan Ongole dalam generasi G2 melalui aplikasi IB.

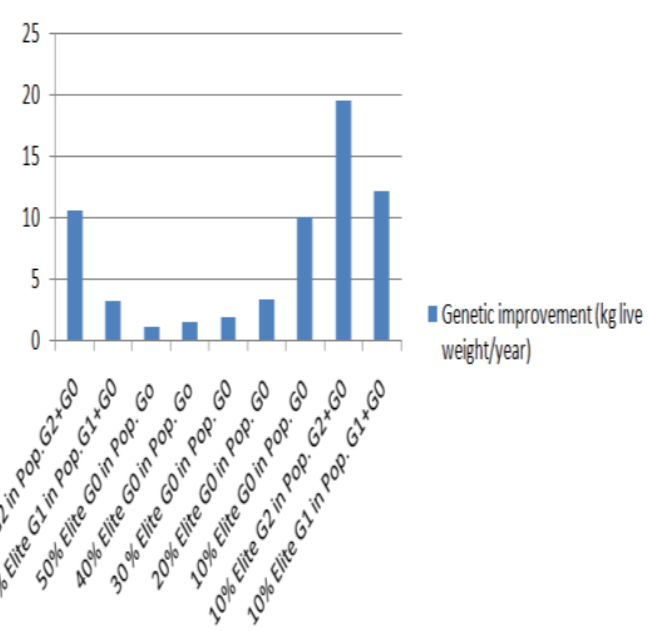

Gambar 2: Variasi rata-rata peningkatan genetik ( $\Delta \mathrm{G} \mathrm{kg} /$ tahun bobot hidup) pada persentase proporsi berbeda dari induk terseleksi elite/unggul G0, G1 dan G2 dalam masing-masing populasi.
Penggunaan $40 \%$ proporsi dari induk G0 (LL) unggul terseleksi $(n=59)$ dari populasi G0 $(\mathrm{N}=147)$ dapat meningkatkan perbaikan genetik hanya $1.58 \mathrm{~kg}$ bobot hidup induk G0 per tahun (Tabel 4). Namun dengan melibatkan proporsi $10 \%$, yang lebih rendah dari proporasi $40 \%$, induk terseleksi G0 dapat mampu menaikkan perbaikan genetic $\left(\left(\Delta_{\mathrm{G}}\right)\right.$ bobot hidup mencapai 10,04 kg/tahun (Tabel 4). Proporsi 10\% untuk induk G0 diharapkan dapat digunakan untuk berkontribusi melalui seleksi induk elite/unggul dalam program perbaikan genetik $(\Delta \mathrm{G})$ terhadap peternak di wilayah pedesaan. Dengan hasil ini, permasalahan perbaikan genetic $(\Delta G)$ ternak yang rendah bagi peternak di pedesaan dapat di atasi dengan percepatan melalui aplikasi kawin IB melibatkan semen pejantan Ongole yang sudah terseleksi dari Balai Besar Inseminasi Buatan sebagai sumber bibit.

Proporsi $48 \%$ induk terseleksi G2 hasil kawin IB dari total populasi G2 dan G0 ( $n=281)$ dapat meningkatkan genetic bobot hidup $(\Delta \mathrm{G})$ 10,66 kg/tahun. Dengan proporsi $10 \%$ seleksi elite G2 dari populasi G2 dan G0 (n=281) dapat meningkatkan genetic bobot hidup $(\Delta \mathrm{G}) 19,46 \mathrm{~kg} /$ tahun (Gambar 2). Proporsi 10\% terhadap seleksi elite induk G0 dan G1 dari total populasi mereka dapat menaikkan rata-rata peningkatan genetik bobot hidup ternak masing-masing secara berurut 10,04 dan 
12,16 kg/tahun (Gambar 2). Dengan demikian, perbedaan penurunan persentase proporsi seleksi dari $50 \%$ sampai $10 \%$ terhadap induk elite G0 dalam populasi mereka sendiri mampu meningkatkan perbaikan genetik $(\Delta \mathrm{G})$ bobot hidup induk dari 1,17 sampai $10,04 \mathrm{~kg} /$ tahun.

\section{KESIMPULAN}

Bardasarkan hasil kajian ini, maka salah satu komponen kritis adalah peningkatan genetik bobot hidup sapi Lokal yang mampu meningkat dengan penggunaan semen pejantan Ongole melalui sistem grading up kawin IB sampai G2 dengan target capaian genetik bobot hidup dari 10,66 kg sampai 19,46 kg per tahun di titik pangkas proporsi $48 \%$ sampai $10 \%$ induk elite/unggul terseleksi di wilayah Sulawesi Utara. Bangsa sapi Ongole memiliki ukuran lebih besar dan dapat diterima masyarakat Sulawesi Utara sebagai sumber produksi daging sehingga dapat direkomendasikan dalam proyek perbaikan genetik bobot hidup disertai relatif rendahnya biaya pakan sehingga cocok bagi peternak di wilayah pedesaan Sulawesi Utara.

\section{UCAPAN TERIMA KASIH}

Ucapan terima kasih dan penghargaan disampaikan kepada pihak Universitas Sam Ratulangi yang telah mendanai penelitian ini melalui skim "Riset Terapan Unggulan Universitas".

\section{DAFTAR PUSTAKA}

Bhakat, M., T.K. Mohanty, V.S. Raina, A.K. Gupta, H.M. Khan, R.K. Mahapatra and M. Sarkar. 2011. Effect of age and season on semen quality parameters in Sahiwal bulls. Tropical Animal Health and Production, 43(6): 1161-1168.

Brito, L.F.C., A.E.D.F. Silva, L.H. Rodrigues, F.V. Vieira, L.A.G. Deragon and J.P. Kastelic. 2002. Effects of environmental factors, age and genotype on sperm production and semen quality in Bos indicus and Bos taurus AI bulls in Brazil. Animal Reproduction Science, 70(3-4): 181190.

Byrkit, D.R. 1987. Statistics Today: A Comprehensive Introduction. The Benjamin/Cummings Publishing Company, Inc. 2727 Sand Hill Road Menlo Park, California, 94025, USA.

Chawala, A.R., G. Banos, D.M. Komwihangilo, A. Peters and M.G.G. Chagunda. 2017. Phenotypic and genetic parameters for selected production and reproduction traits of Mpwapwa cattle in low-input production systems. South African Journal of Animal Science, Volume 47, Number 3: 307-319.

Eidan, S.M. 2016. Effect on postcryopreserved semen characteristics of Holstein bulls of adding 
combinations of vitamin $\mathrm{C}$ and either catalase or reduced glutathione to Tris extender. Animal Reproduction Science, 167: 1-7.

Ellen, E.D., W.M. Muir, F. Teuscher and P. Bijma. 2007. Genetic improvement of traits affected by interactions among individuals: Sib selection schemes. Genetics 176:489-499.

Henchion, M., M. McCarthy, V.C. Resconi and D. Troy. 2014. Meat consumption: Trends and quality matters. Meat Science, 98(3): 561568.

Hendrik, J.M. and U. Paputungan. 2016. Evaluation of parental dam birth weights associated with weights and calving ease of female progeny of the Indonesiangrade cattle. Livestock Research for Rural Development. Volume 28 (6): \#100.

Isnaini, N., S. Wahjuningsih and E. Adhitama. 2019. Seasonal effects on semen quality of Ongole crossbred and Simmental bulls used for artificial insemination. Livestock Research for Rural Development. Volume 31 (2):\# 16.

Kurnianto, E. 2010. Ilmu PemuliaanTernak. Edisi Pertama, Cetakan Pertama. Badan Penerbit, Universitas Diponegoro, Semarang. Page 13.

Mendenhall, W. 1987. Introduction to Probability and Statistics. Seventh Ed. PWS Publishers. 20 Park Plaza. Boston, Massachusetts, USA.

Morrell, J.M. 2011. Artificial insemination: current and future trends. In Artificial insemination in farm animals. IntechOpen. London, United Kingdom.
Nichi, M., P.E.J. Bols, R.M. Züge, V.H. Barnabe, I.G.F. Goovaerts, R.C. Barnabe and C.N.M. Cortada. 2006. Seasonal variation in semen quality in Bos indicus and Bos taurus bulls raised under tropical conditions. Theriogenology, 66(4): 822-828.

Paputungan, U., J.M. Hendrik, A. Lomboan and K. Maaruf. 2015. Study of Indonesian Ongole-crossbred cattle production and income over feed cost for supplements of agricultural waste product formulated in the urea palm sugar block. Livestock Research for Rural Development. Volume 27 (8):\#167.

Paputungan, U., L. Hakim, G. Ciptadi and H.F.N. Lapian. 2013. The estimation accuracy of live weight from metric body measurements in Ongole grade cows. Journal of the Indonesian Tropical Animal Agriculture 38 (3): 149-155.

Paputungan, U., L. Hakim, G. Ciptadi and H.F.N. Lapian. 2016. Evaluation of growth hormone genotypes associated with live weight of progeny generation $\left(\mathrm{G}_{1}\right)$ derived from parental generation $\left(\mathrm{G}_{0}\right)$ of Indonesian grade cattle. Livestock Research for Rural Development. Volume 28 (2):\#28.

Paputungan, U., M.J. Hendrik and W. Utiah. 2018. Predicting live weight of Indonesian Local-Bali cattle using body volume formula. Livestock Research for Rural Development. Volume 30 (8): \#144.

Steel, R.G.D. and J.H. Torrie. 1993. Principles and Procedures of Statistics. Second edition. McGrawHill Book Co. Inc. Singapore.

Thekkoot, D. 2017. Selection Intensity and Genetic Improvement. The University of Alberta and Genesus Inc. Animal breeding aims to 
improve livestock population by utilizing the genetic differences among individuals.

Thundathil, J.C., A.L. Dance and J.P. Kastelic. 2016. Fertility management of bulls to improve beef cattle productivity. Theriogenology, 86(1): 397-405.
Van Vleck, L. D., E.J. Pollak and E.A.B. Oltnacu. 1987. Genetics for the Animal Science. W.H. Freeman and Company, New York.

Zulkharnaim, Z., J. Jakaria and R. Noor. 2010. Identifikasi keragaman genetic gen reseptor hormone pertumbuhan (GHRIAlu I) pada sapi Bali. Media Peternakan 33 (2):81-87. 